\title{
Physician Incomes in the Twenty-First Century: Time for a New Social Contract
}

\author{
Michael L. Millenson ${ }^{7,2}$ \\ ${ }^{1}$ Health Quality Advisors LLC Highland Park, IL, USA; ${ }^{2}$ Feinberg School of Medicine, Northwestern University Chicago, IL, USA.
}

J Gen Intern Med 30(4):400

DOI: $10.1007 / \mathrm{s} 11606-015-3192-\mathrm{y}$

(c) Society of General Internal Medicine 2015

$\mathrm{T}_{\mathrm{T}}$ o the Editor:

The suggestion by Richard L. Kravitz that physician incomes be tied to the average industrial wage is intriguing, ${ }^{1}$ although total health care costs may be related more to the doctor's pen (or keyboard) than what's in his or her pocket. Nonetheless, the issue of physician income and how it's earned has long raised troubling questions.

Back in 1904, the Journal of the American Medical Association approvingly quoted a popular magazine's editorial about the resistance of "the reputable physician" to "commercial methods," while also acknowledging the problem of "merchant doctors" afflicted by "money madness." ${ }^{2}$ Similarly, the founders in 1913 of the American College of Surgeons (ACS) included a vow by its members to shun the "dishonest money-seeking and commercialism" then seen as rampant. ${ }^{3}$

Nonetheless, professionalism alone never proved an adequate prophylactic. During the 1950 s, a period that some like to call a "Golden Age," far too many doctors grasped for the gold. With private health insurance increasingly common, the lay press and medical journals alike were filled with tales of appendectomies for stomach aches, hysterectomies for back pain, "ghost surgeries," fee splitting and similar abuses. ${ }^{4}$ Leaders of the American Medical Association (AMA) and ACS tried and failed to stop the abuses.
A 1955 AMA report found that doctors "display a consistent preoccupation with their economic insecurity. They think about money a lot-about how to increase their incomes, about the cost of running their offices, about what their colleagues in other specialties make, about what plumbers make for house calls and what a liquor dealer's net is compared to their own." 5

When Medicare took effect in 1966, it essentially let doctors set their own "usual, customary and reasonable" fees. The AMA pleaded again for restraint, but the imperative of banishing financial insecurity won out.

Perhaps, as Kravitz suggests, now is the time to move towards a new social contract. Its terms would secure appropriate income and autonomy for physicians in return for a professional embrace of accountability to provide safe, evidence-based and compassionate care.

Corresponding Author: Michael L. Millenson, Health Quality Advisors LLC Highland Park, IL, USA (e-mail: mm@healthqualityadvisors.com).

\section{REFERENCES}

1. Kravitz RL. Physician incomes in the twenty-first century: Time for a new social contract. J Gen Intern Med. 2014;29(11):1425-26.

2. JAMA 100 years ago: Does it pay to be a doctor? JAMA 2004;291(4):502.

3. Rodwin MA. The organized medical profession's response to financial conflicts of interest: 1890-1992. Milbank Q. 1992;70(4):703-741.

4. Millenson ML. Demanding medical excellence: doctors and accountability in the information age. New York: University of Chicago; 1997:148-51.

5. Carter R. The doctor business. New York: Doubleday; 1958:74.

Published online January 29, 2015 